\title{
Totalitarianism and the
}

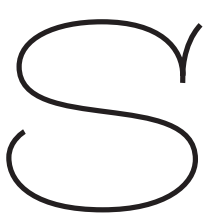

Violation of Human Rights

in Education. The Case

of Slovenia

\section{Ingrid Kodelja ${ }^{a}$}

\section{Zdenko Kodelja ${ }^{b}$}

a Free researcher, Slovenia

ingrid.kodelja@siol.net

b Educational Research Institute, Ljubljana, Slovenia

zdenko.kodelja@guest.arnes.si

Received 3 November 2020

Accepted 28 January 2021

Available online 31 August 2021

DOI 10.15240/tul/006/2021-1-009
Abstract Slovenian schools were victims of the totalitarianism of Italian Fascism from the advent of fascist rule in 1922 until the capitulation of Italy in 1943 and of German Nazism during World War II (1941-1945). However, the question remains whether schools in Slovenia were victims of totalitarianism after the war, too. The answer depends on whether the socialist regime was merely undemocratic or also totalitarian. But even if the state at that time was not totalitarian, it violated human rights also in the field of education. According to the European Court of Human Rights, the State is forbidden to pursue an aim of indoctrination in public schools - as was the case in Slovenia - because indoctrination is con-

sidered to not respect parents' religious and philosophical convictions. In this paper it will be shown that the state also violated two other human rights of their citizens which are in close connection to this parents' right, namely, the right of parents to choose private schools based on specific moral, religious or secular values; and (if there are not such schools) the right to establish them. Both of these rights were violated because private schools, except religious schools for the education of priests, were forbidden. These rights were violated in the socialist republic of Slovenia even though ex-Yugoslavia (one of whose constitutive parts was at that time Slovenia) signed and ratified these international documents on human rights.

Keywords indoctrination, human rights, public schools, totalitarianism

Slovenian schools were the first victims of Italian fascism before World War II in Europe. In addition, during the war, in one part of Slovene territory schools were subjected to the repression of German Nazism as well. In both cases, they were, therefore, the victims of totalitarianism. 
There are several definitions of totalitarianism. ${ }^{1}$ Since the purpose of this paper is not to analyse the various philosophical and sociological definitions of this concept, we proceed from the generally accepted view that fascism, Nazism and communism were totalitarian regimes.

\section{"Slovenian" Schools in the Time of Fascism}

Before World War I, the entire territory of present-day Slovenia was under the Austro-Hungarian monarchy. Slovenians were able to study in their mother tongue, since the state law on universal rights of citizenship of 1867 clearly stated in Article 19 that "the state recognizes the equality of all provincial languages at school” (Schmidt, 1988, p. 320).

After World War I, a large part of Slovenian territory, Primorska - or the western part of the territory-belonged to the Kingdom of Italy. The pre-fascist liberal governments acknowledged the existence of Slavic minorities in Italy and, by a resolution filed in parliament by the Socialists, assured them that they would be able to use their language and cultivate their culture and religion without restrictions or obstacles. However, these promises were not fulfilled, and with the advent of fascist rule in 1922, things changed fundamentally (Kacin Wohinz \& Verginella, 2008, p. 31). The recognition of the existence of national minorities was incompatible with the fascist doctrine of the superiority of the Italian people. Fascist politics was based on the denial of the existence of national minorities, on the belief that they were undeveloped second-class groups that were doomed to assimilation and Italianization (ibid., pp. 33-34). The Italianization policy was felt by Slovenes in Italy in all areas of social life, in administration, in the Church,

1 One of the most widely accepted definitions of totalitarianism is the definition of Carl J. Friedrich and Zbignew K. Brzezinski in The Totalitarian Dictatorship and Autocracy (1956). This definition served as a reference for US policy during the Cold War and as a conceptual framework for a whole generation of researchers in political science and history for the study of the USSR. It focuses on six fundamental characteristics: an official ideology embracing the totality of life; a single party of mass and subject to a charismatic leader; a police control resorting to terror and directed by a secret police; a monopoly of the means of mass communication; a monopoly of arms; a planning and centralized control of the economy. 
in the economy, in language, in culture, and in education. The use of the Slovenian language was banned in all public places. Slovenian schools were hit with a decisive blow by the so-called Gentile ${ }^{2}$ school reform in 1923, especially by the reform's fourth and seventeenth articles. Article 4 stated that instruction in all primary schools should be provided in the state language, i.e. Italian. Slovene could be taught at extra hours at the special request of parents, but this option was abolished in 1925 with the Fedele reform. Article 17, however, provided that, as of the beginning of the 1923/24 school year, Italian should be introduced as the language of instruction in all first grades of foreign language primary schools. Slovenian was thus to be gradually phased out by the 1928/29 school year, but this happened earlier than required by law. Gradually, all Slovenian secondary schools were also abolished. The only public institution where Slovene could be taught in the interwar period was the Small Seminary in Gorizia, at which the Vatican permitted the Slovene language to be used even after the introduction of Gentile's school reform (Vižintin, 2013, pp. 21-23; Kacin Wohinz, 1990, p. 71; Okoliš, 2008, p. 90).

In addition to Italianization, children were also subjected to indoctrination in schools. Fascism spread its ideology in schools as well. Pupils were automatically enrolled in the departments of the unified youth organization the Opera Nazionale Balilla (founded in 1926), renamed the Gioventù Italiana del Littorio in 1937. In the mid-thirties,

2 Giovanni Gentile (1875-1944) was an Italian neo-Hegelian idealist philosopher, educator, and fascist politician. The self-styled "philosopher of Fascism", he was influential in providing an intellectual foundation for Italian Fascism, and ghostwrote part of The Doctrine of Fascism (1932) with Benito Mussolini. As a minister of Mussolini's government, he was the author of the fascist education reform, known to Primorska Slovenes as Gentile's reform. It was adopted on 1 October 1923. This was part of the fascist plan to denationalize the annexed Slovene and Croatian territory, or more precisely the ethnocide against Slovenes and Croats in Italy. On the basis of this plan, all slovene and Croatian schools, which until then had managed to maintain their mother tongue lessons (more than 400), were abolished and replaced by the teaching of Italian, which they carried out in the very rude ways ('Giovanni Gentile' in Encyclopaedia Britannica, 2021; Wikipedia, 2019). 
organizations for pre-school children - Figli and Figlie della Lupa - were created. These organizations wanted to bring youth into fascist society through military discipline, sports, political events and propaganda (ibid., pp. 58-60). Schools in general became a means of consolidating a totalitarian fascist state. In the interwar period, almost all Slovenian teachers were forcibly replaced by Italian teachers so that lessons were taught exclusively in Italian. All Slovenian teachers who did not flee to Yugoslavia or abroad were expelled under police control to the south of Italy. Teachers played a major role in the spread of fascist propaganda among young people. Children used to sing fascist songs, learn fascist slogans and listen to Mussolini's speeches. The teachers had to be welcomed by the students with a fascist salute. In addition to the compulsory lessons, students were also required to attend so-called Fascist Saturdays, which extolled the fascist regime and glorified Mussolini. They had to wear special uniforms of fascist youth organizations that varied by the gender and age group of the students.

In this context, the results of a survey of the memories and feelings of Slovenes who attended Italian schools is interesting (Vižintin, 2013, pp. 38-39, 50-54). The author of the research says that those who started schooling before the introduction of Gentile's reform and who had previously studied in the Slovene language have negative memories. In particular, those who first encountered fascism as teenagers and in high school already had a largely national consciousness and were most affected by the reform. In contrast, most of those who began their education in Italian have positive memories. They say that other than the reality that they spoke Slovenian at home and Italian at school, they were not at all aware of any injustice. There is also a difference between village and bourgeois children. The village children were taught in Italian, but during the breaks they were mostly able to speak in Slovenian without serious consequences. In the ethnically mixed cities of Gorizia and Trieste, the regime was stricter and Slovene could not be used even on the street. Many therefore felt inferior. Those who came from poor families also have positive memories of schooling during fascism. Schools enabled them to play and socialize with peers within the framework of so-called Fascist Saturdays, enjoy 
food and appearances at public holiday gatherings, and attend summer colonies at the seaside, etc. The vast majority of those who fondly remember their fascist education say that despite their parents' warnings, they were not aware that they were manipulated and indoctrinated at school. This still gives them a sense of guilt.

A little better was the position of Slovenes in the province of Ljubljana, which was annexed to Italy in 1941 after the disintegration of the Kingdom of Yugoslavia. In the province of Ljubljana, cultural autonomy was recognized for Slovenes, unlike before the war in Primorska, by a special statute. The former Yugoslav school system remained unchanged, changing only the curricula for history (emphasizing Italian-Roman history), geography and national science. At all levels of education, compulsory instruction was in Slovene, and Italian was optional. This arrangement was supposed to be only temporary, and the Italian authorities also here wanted to completely replace Slovenian education with Italian. Fascist pressure was exerted on schools in the Ljubljana region by introducing a mandatory fascist salute and by forcibly recruiting children and teachers into fascist youth and workers' organizations. Here too, the fascists tried to gain the affection of children with various benefits, from organizing school meals to participating in sports organizations and giving gifts. With the strengthening of the Slovenian liberation movement, the Italian occupier became increasingly violent. Many Slovenian teachers and even entire classes of students were imprisoned in Italian internment camps. At the Gonars camp, at the end of the 1942/43 school year, students even took the matura exam (Okoliš, 2008, pp. 102-104).

\section{Slovenian Schools under the Nazi Regime during the World War II}

In April 1941, Slovenia was occupied by the armies of three neighbouring countries: Germany, Italy and Hungary. The German occupier was the most ruthless and violent of the three regarding the procedures and methods of assimilation. The occupied Slovenian territories of Styria, Carinthia and Gorenjska were annexed to the Third Reich. All Slovenian schools were abolished, many Slovenian teachers were cast 
out to Croatia and Serbia or deported to German labour camps. In the occupied territories, German schools and kindergartens were introduced with German teachers who mostly did not have a proper pedagogical education and did not know the Slovene language. The use of Slovenian was forbidden also during breaks. German language classes, which were not only language lessons but also propaganda for Hitler and the Third Reich, were introduced. Nazi youth organizations, like the Deutsche Jugend and the Volksbundjugend, were closely associated with the schools (Okoliš, 2008, pp. 100-102). These organizations were a very important part of Nazi education, which is usually interpreted as indoctrination since it was based on racist ideology and anti-humanism (Reboul, 1977, pp. 131-171).

Although there are similarities and differences between fascism and Nazism, both are generally considered as paradigmatic examples of totalitarianism. In both cases, Slovenian schools in the territory under fascist and Nazi powers were therefore victims of totalitarianism. However, there is no consensus on whether schools were victims of a third totalitarianism after the war: communism. Some believe that the post-war socialist regime in Slovenia was undemocratic, but not totalitarian in terms of the regimes in Eastern Europe. ${ }^{3}$ In any case,

"In 2011 the Constitutional Court of Slovenia designated the entire political order during 1945-1990, [...] as 'totalitarian'. However, the Constitutional Court did not invoke any systematic treatments of totalitarianism, nor did it analyse this phenomenon and its presence in the time period referred to. One cannot deny that in 1945 Yugoslavia was established predominantly as a totalitarian state” (Flere, 2013, p. 116). But Slovenian sociologist Sergej Flere in his analysis "denies that the order in Yugoslavia after the 1960s was totalitarian, and in particular not with respect to any of the elements laid down by Carl Friedrich and Zbigniew Brzezinski in their classic study (1956). In Yugoslavia during the 1960s, e.g. millions of copies of religious materials were freely published annually, economic firms did not operate within a non-monetary planned economy; although the political system was officially a one-party one, republics (as of 1971 also provinces) acted as autonomous political entities, taking care of their interests and conflicting mutually. Although Tito was appointed president with a life mandate and his cult proliferated, his actual power was limited by the federal nature of the state and opposing federal units. Also, with respect to no other elements noted by the authors there is no reason for Yugoslavia to be designated a totalitarian state as of the middle of the 1960s" 
this was a regime in which some human rights were violated because private schools were banned, and in public schools, if they followed the demands of the Communist Party, they would have to indoctrinate, that is, to inculcate Marxist ideology.

\section{The Violation of the Right of Parents to Establish and Choose Private Schools after World War II}

The right of parents to choose private schools would be worthless if at the same time the right to establish private schools did not exist. ${ }^{4}$ And the opposite: the right to establish such schools would be worthless without recognition of the right of parents to choose them. It is evident, therefore, that the question of which of these two rights comes first makes no sense if we judge it from the logical point of view, for there is no before and after. But looking from the historical point of view, the right to establish such schools comes before the right to choose them and makes the choice possible (Bobbio, 1986, p. 17).

The right of parents to choose private schools - or more precisely, schools other than those established or maintained by the public authorities - for their children is recognised as a human right in two important international documents: firstly, in the International Covenant on Economic, Social and Cultural Rights, ${ }^{5}$ and secondly,

(Ibid.). The political alliance between the Soviet Union and Federal Yugoslavia (of which Slovenia was part) lasted only from 1945 to 1948, when the Yugoslav Communist Party was expelled from the Soviet-dominated international communist organization. The political break with the Soviet Union in 1948 did not however, mark a clean break with Soviet educational thinking. Nevertheless, from 1950 the Soviet model of educational theory was gradually replaced with more independent educational thinking.

4 Since 1950 religious communities have been allowed to establish religious schools for the education of priests (The Constitution of the SR of Slovenia, 1974, Article 229; Šimenc, 1996, p. 39). However, their right is limited and very different from the right to establish private schools, as it is formulated in the international documents on human rights.

5 "The States Parties to the present Covenant undertake to have respect for the liberty of parents and, when applicable, legal guardians, to choose for their 
in the Convention Against Discrimination in Education. ${ }^{6}$ In both documents, this right of parents is defined as a right to liberty of choice. That is to say, it is defined as the liberty of parents to choose private schools. This right is correlative to the duty of the State to refrain from imposing on them an obligation to send their children to public schools. Defined in such a way, the discussed right is understood as freedom from the State monopoly in education. Therefore, this right of parents, as well as other individual human rights, requires the State to limit its power. ${ }^{7}$ All States that have ratified the mentioned international documents on human rights have voluntarily accepted this limitation of their sovereign power in relation to their citizens. ${ }^{8}$ However, this was not enough for protecting the discussed parents' right. The former Yugoslavia ratified, among other international documents on human rights, the Convention Against Discrimination in Education in 1964 and the International Covenant on Economic, Social and Cultural Rights in 1971. But despite this, all private schools except seminaries and faculties of theology were legally prohibited on its territory not only before but also after ratification. In Slovenia, for example, private schools were abolished after World War II, when the Republic of Slovenia became a constitutive part of Yugoslavia, and they have been permitted again since 1991, when Slovenia became an independent state. ${ }^{9}$ In this case

children schools, other than those established by the public authorities" (International Covenant on Economic, Social and Cultural Rights, 1966, Art. 13.3).

6 "It is essential to respect the liberty of parents and, where applicable, of legal guardians, [...] to choose for their children institutions other than those maintained by the public authorities" (Convention Against Discrimination in Education, 1960, Art. 5. 1.b).

7 Cf. Haarscher, 1993, pp. 11-12, 38-39.

8 The States have themselves limited their internal sovereignty (Rendel, 1997, p. 23). Internal sovereignty is subordinate to international law, which is a product of consensualism, but limits the arbitrary exercise of power. Nothing can be imposed on those who govern without their consent. National sovereignty is in this way safeguarded (Bettati, 1996, pp. 91, 100-101).

9 In 1945, all private schools were banned. The exception was religious schools for the education of priests, which have been allowed to be established by religious communities since 1950. But the certificates of these schools did not have 
it is totally clear that the State respected neither the liberty of parents to choose private schools for their children, nor the right of individuals and bodies to establish and direct private schools.

However, although the previously mentioned international documents on human rights guarantee the right of parents to choose private schools, this does not mean that parents' liberty of choice is unlimited. On the contrary, it is restricted. On the one hand, parents have freedom in their choice of schools only in relation to the State, but not necessarily also in relation to the religious communities or churches to which they belong. Parents belonging to the Catholic Church, for instance, have a duty to send their children to Catholic schools wherever this is possible. ${ }^{10}$ On the other hand, parents are permitted to choose only those private schools "which conform to such minimum educational standards as may be laid down or approved by the State" (International Covenant on Economic, Social and Cultural Rights, Art. 13.3) or "by the public authorities" (Convention Against Discrimination in Education, Art. 5.1.b). Therefore, the State is not only obliged to permit parents' liberty of choice but also to limit it.

public validity. Two such Catholic secondary religious schools were established, but their completion allowed enrolment only in the Faculty of Theology. If graduates of these schools wanted to enrol in other colleges or universities, they had to pass exams at state gymnasiums (cf. Šimenc, 1996, p. 39). This means that these schools were in some sense private, but all other types of private schools (including religious ones) that we usually think of when we talk about private schools were banned. Since 1991, the existence of private schools has again been permitted thanks to the new concept of the educational system in Slovenia, which is founded on the basis of human rights and other political, cultural and moral values which lie at the root of a civilized society: pluralist democracy, tolerance, solidarity and the rule of law (The European Dimension of Education: Teaching and Curriculum Content; Résolution de la Conférence permanente des Ministres européens de l'Education sur 'la dimension européenne de l'éducation: pratique de l'enseignement et contenu des programmes', 1991, p. 3, 5).

"Parents are to send their children to those schools, which will provide for their Catholic education. If they cannot do this, they are bound to ensure the proper Catholic education of their children outside the school" (Codex Iuris Canonici, 1983, Can. 798). 
Nevertheless, although this parental right is limited, there is no doubt that it was violated in Slovenia after World War II, when it was one of the six socialist republics of federal Yugoslavia. If we consider two additional facts - firstly, that parents were legally obligated to send their children to public schools, and secondly, that the education in these public schools was, or at least was supposed to be, based on Marxist ideology - then we can conclude that the State violated another internationally recognised parent's right, the right "to ensure religious and moral education of their children in conformity with their own convictions" (The International Covenant on Economic, Social and Cultural Rights, 13.3) in public schools.

\section{The Violation of the Right of Parents to Educate their Children in Conformity with Their Own Religious or Philosophical}

\section{Convictions in Public Schools}

According to the European Court of Human Rights, the State is forbidden from pursuing an aim of indoctrination in public schools because indoctrination is considered to not respect parents' religious and philosophical convictions (Digest of Strasbourg Case - Law relating to the European Convention on Human Rights, 1985, pp. 810-811). According to its interpretation, the State must "protect the children of certain parents from compulsory religious or philosophical instruction which is not directed at providing information but which is concerned with indoctrinating children with unacceptable beliefs, convictions or ideologies" (ibid., p. 801)..$^{11}$ Countries where the parental right has been violated were formerly the communist, including Slovenia - there were parents legally obligated to send their children to public schools in which education was, or at least was supposed to be,

11 Here, once again, it is not clear whether indoctrination is forbidden because beliefs, convictions or ideologies are unacceptable, or because indoctrination itself is not acceptable. Unacceptable for whom? It seems for parents. But would indoctrination of children be acceptable if these beliefs, convictions or ideologies were acceptable for their parents? 
based on Marxist ideology. ${ }^{12}$ But this phenomenon of indoctrination was not unique to communist regimes. Before World War II, the Catholic Church in some European countries also required that all school subjects in public schools, even mathematics and the natural sciences, would be permeated with Catholicism. ${ }^{13}$ In these cases, Marxism and Catholicism were seen as indoctrination and, as such, a violation of the right of parents to educate their children in public schools in accordance with their own religious or philosophical convictions.

But in the context of the discussed international documents on human rights, two things are not clear enough. Firstly, it is not obvious what exactly is meant by indoctrination. The Court's interpretation gives the impression that only one criterion of indoctrination has been used: aim or intention. Accordingly, indoctrination is forbidden as the aim of religious or philosophical instruction in public schools. ${ }^{14}$ Secondly, it is not evident why indoctrination is forbidden. It is clear, of course, that it is forbidden because it is seen as something bad. But the question remains: is it forbidden because it is bad in itself or because it is bad only as a violation of parents' right to educate their

12 In 1974, the Communist Party demanded: "It is urgent [...] that young and adult accept Marxism as their worldview. [...] This binds all factors of education to be combative and critical in the educational work of all non-scientific, anti-Marxist theories, ideas and ideologies that are alien to socialist self-government, as well as to their bearers" (Deseti kongres, 1974, p. 321).

13 In the Encyclical on Christian Education (Divini Illius Magistri) given by Pope Pius XI in 1929, it is clearly stated: "It is necessary not only that religious instruction be given to the young at certain fixed times, but also that every other subject taught, be permeated with Christian piety" (Point 80). Even more, "it is necessary that all the teaching and the whole organization of the school, and its teachers, syllabus and text-books in every branch be regulated by the Christian spirit, under the direction and maternal supervision of the Church" (ibid.).

14 Yet, if the requirements - that the State "must take care that information or knowledge included in the curriculum is conveyed in an objective, critical and pluralistic manner" (Digest of Strasbourg Case - Law relating to the European Convention on Human Rights, 1985, pp. 810-811); and that the exemption from "compulsory education in one religion" must be allowed because it means teaching "unacceptable beliefs, convictions or ideologies" - are understood as prevention of indoctrination, then the method and content criterion of indoctrination have been used too. 
children in conformity with their own religious or philosophical convictions? If it was forbidden because it is bad in itself, then we would expect it to be forbidden also in private schools and at home as well. Since indoctrination is not explicitly forbidden there, it might make someone believe that it is forbidden because it is in opposition with the previously mentioned parents' right. If so, then it seems that we should conclude either that indoctrination is something good when the indoctrinators are parents or teachers in private schools who indoctrinate children in accordance with their parents' religious or philosophical convictions, or that indoctrination in such cases is not possible. If we understand indoctrination in the sense which it has in predominant philosophical theories of indoctrination, then both conclusions are false, since indoctrination is in contemporary philosophy of education commonly seen as something bad and immoral. ${ }^{15}$ If so, then indoctrination is a bad thing also when children are indoctrinated by their parents or by teachers who indoctrinate children in accordance with their parents' religious or philosophical convictions in private schools. On the other hand, there is no evidence that indoctrination in such cases would be impossible. It might be argued that just the opposite is true. Religious education is namely often given as a paradigmatic case of indoctrination (Snook, 1972, pp. 76-79). But this does not mean that all religious or philosophical education is indoctrination. It means that some forms of religious or philosophical education could become indoctrination, while others are - at least according to the European Court of Human Rights - not understood as indoctrination if such teaching "is conveyed in an objective, critical and pluralistic manner" (Digest of Strasbourg Case - Law relating to the European Convention on Human Rights, 1985, pp. 810-811).

15 In the past, indoctrination was not always understood as blameworthy. In the Middle Ages indoctrination indicated the implanting of Christian doctrine. As such, "indoctrination" was synonymous with education and it did not have a pejorative connotation. Later on, indoctrination "gradually assumed the connotations of a coercive type of education" and has acquired a negative meaning (Gatchel, 1972, pp. 11-13). 
These conceptual differences must be considered when we speak of indoctrination as a violation of the aforementioned human rights. It would also be a mistake to see such a violation of human rights as something specific only to communist countries. Nevertheless, there is no doubt that the violation of these human rights was an important feature of what was then Slovenia, even if it was not - as some claim a totalitarian country.

\section{Bibliography}

'Giovanni Gentile'. Encyclopaedia Britannica [online]. [cit. 2021-05-26]. Available at: https://www.britannica.com/biography/Giovanni-Gentile.

'Giovanni Gentile'. Wikipedia [online]. [cit. 2019-10-27]. Available at: https://sl.wikipedia.org/wiki/Giovanni_Gentile.

BETTATI, Mario, 1996. "The International Community and Limitations of Sovereignty". Diogenes 1996/44, pp. 91-109.

BOBBIO, Norberto, 1986. "Libertà nella scuola e libertà della scuola". In: Stato e scuola oggi: l'opinione laica. Napoli: Edizioni Scientifiche Italiane.

Codex Iuris Canonici [online], 1983. [cit. 2020-12-17] Available at: http://www.vatican.va/archive/cod-iuris-canonici/cic_index_la.html.

Convention Against Discrimination in Education, 1960. UNESCO.

Deseti kongres ZKJ, 1974. Ljubljana: Komunist.

Digest of Strasbourg Case - Law relating to the European Convention on Human Rights, 1985. Vol. 5. Köln, Berlin, Bonn, Munich: C. Heymanns, Verlag, K. G. ISBN 3452195260.

FLERE, Sergej, 2013. “Titova država, 'totalitarna'?”. Teorija in praksa. 2013/1, pp. 116-131. ISSN 0040-3598.

FRIEDRICH, Carl J. \& BRZEZINSKI, Zbignew K., 1956. The Totalitarian Dictatorship and Autocracy. Cambridge Mass.: Harvard University Press. ISBN 9780674332607.

GABRIČ, Aleš, 2009. Sledi šolskega razvoja na Slovenskem [online]. Ljubljana: Pedagoški inštitut [cit. 2019-11-27]. ISBN-13 (HTML): 978-961-270-016-4. Available at: https://www.sistory.si/cdn/publikacije/11000/913/ SLEDI_SOLSKEGA_RAZVOJA_NA_SLOVENSKEM.pdf.

GATCHEL, R. H., 1972. “The Evolution of the Concept”. In: SNOOK, I. A. Concepts of Indoctrination. London and Boston: Routledge and Kegan Paul. ISBN 0710072791. 
HAARSCHER, Guy, 1993. Philosophie des droits de l'homme. Bruxelles: Editions de l'Université de Bruxelles. ISBN-10: 2800410744, ISBN-13: 978-2800410746.

International Covenant on Economic, Social and Cultural Rights, 1966. UN.

KACIN WOHINZ, Milica \& VERGINELLA, Marta, 2008. Primorski upor fašizmu 1920-1941. Ljubljana: Slovenska matica. ISBN 978-961-213-178-4.

KACIN WOHINZ, Milica, 1990. Prvi antifašizem v Evropi: Primorska 1925-1935. Koper: Lipa. ISSN 0350-5774.

OKOLIŠ, Stane, 2008. Zgodovina šolstva na Slovenskem [online]. Ljubljana: Slovenski šolski muzej [cit. 2019-10-23]. ISBN 978-961-6764-00-1. Available at: https://stanko-okolis.si/wp-content/uploads/2018/05/Zgodovina-\%C5\%A1olstva-na-Slovenskem.pdf.

PIO, PP. XI., 1929. Divini Illius Magistri [online]. Lettera enciclica di sua santità Pio PP. XI. Sulla educazione Cristiana della gioventù [cit. 2020-12-15]. Available at: http://www.vatican.va/content/pius-xi/it/encyclicals/ documents/hf_pxi_enc_31121929_divini-illius-magistri.html.

PROTNER, Edvard, 2010. "General Education Private Schools in Slovenia from the Past to the Present". Sodobna pedagogika. Journal of Contemporary Educational Studies [online]. Vol. 61, No. 5, pp. 60-80 [cit. 2020-11-29]. Available at: https://www.sodobna-pedagogika.net/en/articles/05-2010_general-education-private-schools-in-slovenia-from-the-past-to-the-present/.

REBOUL, Olivier, 1977. L'endoctrinement. Paris: Puf. ISBN 102130349811.

RENDEL, Margherita, 1997. Whose Human Rights?. Oakhill: Trentham Books. ISBN 1-85856-057-8.

SCHMIDT, Vlado, 1988. Zgodovina šolstva in pedagogike na Slovenskem 3. Ljubljana: Delavska enotnost. ISBN 863710066X.

ŠIMENC, Marjan, 1996. “Zasebno šolstvo”. In: ŠIMENC, Marjan \& KREK, Janez. Zasebno šolstvo: struktura, primerjava različnih šolskih sistemov in zakonodajne rešitve $v$ Republiki Sloveniji. Ljubljana: Ministrstvo za šolstvo in šport. ISBN 9616222015 , 9789616222013.

SNOOK, Ivan A., 1972. Indoctrination and Education. London and Boston: Routledge and Kegan Paul. ISBN 0710072228.

The Constitution of the SR of Slovenia, 1974. Ljubljana: Uradni list SR Slovenije.

The European Dimension of Education: Teaching and Curriculum Content; Résolution de la Conférence permanente des Ministres européens de l'Education sur 'la dimension européenne de l'éducation: pratique de l'enseignement et contenu des programmes, 1991/5. Newsletter / Faits nouveaux. Strasbourg: Council of Europe. 
VIŽINTIN, Mojca, 2013. Šolstvo pod fašizmom skozi prizmo Italijanov in Slovencev [online]. Ljubljana [cit. 2019-10-27]. Diplomska naloga. Fakulteta za družbene vede. Gabrič Aleš. Available at: http://dk.fdv.uni-lj.si/diplomska_dela_1/pdfs/ mb11_vizintin-mojca.pdf. 